\title{
IDIOMATIC TRANSLATION METHOD OF ENGLISH INDONESIAN TRANSLATION
}

(A content analysis of a book "the Twilight Saga Breaking dawn" by Stephenie Meyer and "Awal yang Baru” translated by Monica Dwi Chresnayani)

\author{
Muhammad Ajie Akbar \\ Sekolah Tinggi Bahasa Asing- IEC Jakarta \\ ajie.akbar21@yahoo.com \\ Suhendar \\ Sekolah Tinggi Bahasa Asing- IEC Jakarta \\ E-mail: suhendar@stibaiec-jakarta.ac.id
}

\begin{abstract}
Akbar, M.A. and Suhendar. (2020). Idiomatic translation method of English Indonesian translation: A content analysis of a book "the Twilight Saga Breaking dawn" by Stephenie Meyer and "Awal yang Baru" translated by Monica Dwi Chresnayani Journal of English Language and literature, 5(2), 31-40. doi: 10.37110/jell.v5i02.102

Received: 11-07-2020

Accepted: 20-08-2020

Published:01-09-2020

Abstract: The purpose of the research was to analyze the idiomatic translation found in "The Twilight Saga Breaking Dawn" By Stephanie Meyer and "Awal Yang Baru" Translated By Monica Dwi Chresnayani. The result of the research is the idiomatic translations method which is found in the novel and analyzed by using the theory of translation from Newmark. Based on the data analysis, the writer found some proofs that the data which were translated used idiomatic translation method. In analyzing translation process, the writer compared with other translation methods. The purpose was that the writer showed the translation method used by the translator was idiomatic translation method. In translation, the translator paid attention to the meaning of source language so that the message in target language can be received by the readers.
\end{abstract}

Keywords : Idiomatic translation, Newmark Theory, The Twilight Saga Breaking Dawn.

\section{INTRODUCTION}

Language is a natural communication tool for people and it is important for them in their daily lives. Languages express meaning by relating a sign to its meaning or its contents. Therefore, everyone must know foreign language especially English. English is used in global communication even textual, audio or visual media. Especially for literature in English novel that needs deep translation for readers to make them better understand the meanings and messages contained in it, so it is translated into Indonesian.

For understanding other language, translation is needed because not everybody knows about foreign language. Translation is interpretation of meaning from the text in one language, called source language and the result of translation must be equivalent to target language that communicates the same message. The result or translation has to consider several constrains, context, rules of grammar, writing convention, idioms, and other things between source language and target language. The person who translates the text from one language to other language is called translator.

Translation has become one of the most important tools in understanding texts, books, movies, or songs. Translating books from English to Indonesian is not easy, but it should pay attention to the language style of the Source Language (SL) into the Target Language (TL), to match the style that tends to be formal, objective, and standardized. So that the reader be able to receive the content of meaning and the message contained in the books. Indeed, translation is an interesting subject not only for linguist but also for professional, newbie translator and languageteacher. Translation is an interesting subject to 
discuss because translation mediates between languages, societies, and literatures. The master of language translation operate by making communication between speakers of different language.

Unlike what most people think, translation is not just about rendering meaning from one language into another language. There are several things to consider when someone tries to translate from source language to target language such as acuracy, clarity, and naturalness. In fact, many people are not able to translate meaningfully, they always translate it basically, like as word-toword. As for the way to translate, people had different technique. Translation enables learner to understand all parts in the passage.

In translation, there are some contexts such as type, method, procedure, and technique of translation. In this section, communicative method of translation is the specific one and it makes the writer easier to analyze the translation. Idiomatic translation method that used is by author has a purpose to make easier the reader to receive the meaning of the context.

In connection to which, the writer decided to analyze idiomatic translation because there are some reasons. It is a novel as a form of religious reading that is liked by many people, the language is comprehensible, learning about different social culture. Besides, the readers will have fun to read a novel so that they will not be bored.

Based on those previous explanations, the writer finally has decided to be interested to analyze translation about the book and the writer chooses the title "Idiomatic Translation Method of English Indonesian Translation in Book "The Twilight Saga Breaking Dawn" By Stephenie Meyer" for this assignment.

The purpose of this thesis is to analyze idiomatic translation in novel "The Twilight Saga Breaking Dawn" by Stephenie Meyer which has been translated in Bahasa Indonesia by Monica Dwi Chresnayani and it will be seen by the words and the sentences. For analyzing the data, the writer used the method of translation based on Newmark theories. The writer gains the theories from the books and previous relevant researches.

\section{Theory of Translation}

Translation has been defined in many ways by different writers in the field, depending on how they view language and translation. According to Wills in Choliludin, translation is a procedure which leads from a written source language text to an optimally equivalent target language text and requires the syntetic, semantic, stylistic, and text pragmatic comprehension by the translator of the original text.

According to Nida in Elliot's and Boer's book, it is stated that "translating consists of reproducing the receptor language to the closest natural equivalent of source language message, first in the term of meaning and secondly in term of style". Based on above theory, Nida explains that translation is reproducing a language of the source language message as the term of meaning and style. However, translation deals with the meaning. Translation with correct structure is useless without the meaning.

According to Hatim and Munday, "Translation is the process of transferring a written text from SL to TL, conducted by a translator, or tranlators, in a specific sociocultural context." It means that translation is rendering the meaning of the text as a source language into another language as a target language in the way that the text intended by the author in specific socio-cultural context.

Based on some definitions of translation, the writer concludes that translation is a process of transfering the meaning of a language into another language.

\section{Types of Translation}

Translation has some types. Each expert has different statement about types of translation. The writer takes two experts who state about types of translation based on classification.

According to Larson in Choliludin translation is classified into two main types, they are :

a. Namely Form-Based

"Namely form-based attemps to follow the form of Source Language and is known as literal translation." It means that namely form-based is a translation that follow the form of source language.

b. Meaning Form-Based

"Meaning form-based translation makes every effort to communicate the meaning of the SL text in the natural forms of the receptor language." It means that meaning form-based is a translation that translated the meaning of the SL text in the natural form. 
According to Brislin in Choliludin, based on the purposes of translation, there are four types of translation, among others are:

a. Pragmatic Translation

"Pragmatic Translation refers to the translation of a message with an interest in accuracy of the information that was meant to be conveyed in the source language form and it is not concerned with other aspects of the original language version." It means that pragmatic translation is a translation of a message that emphasizes accuracy of the information in target language and not pays attention aspects of the source language.

b. Aesthetic-poetic Translation

"Aesthetic-poetic translation refers to translation in which the translator take into account the affect, emotion, and feelings of an original agnate version, the aesthetic form used by the original author, as well as any information in the message." Based on the explanation, aesthetic-poetic translation is a translation that pays attention to gracious aspects, emotion aspects, and feeling aspects of an original version.

c. Ethnographic Translation

"The purpose of ethnographic translation is to explicate the culture context of the source and TL versions. Translators have to be sensitive to the way words are used and must know how the words fit into cultures." Translators have to be sensitive to different words used that resemble in form and meaning in the language.

\section{Kinds of Translation Method}

In translation context there are some different ways to translate specially of translation method. Translating language has different ways based on types of the context and the translator.

According to Molina and Albir "Translation method refers to the way of particular translation process that is carried out in terms of the translator's objective, i.e, a global option that affects the whole texts." It means that translation method used when translating influence translation result.

Newmark states that there are some translation methods that list four kinds of translations with emphasis on the source language : Word-for-Word translation, Literal Translation, Faithful Translation, and Semantic Translation. It also lists four kinds of translations with emphasis on the target language : Adaptation, Free Translation, Idiomatic Translation, and Communicative Translation.

There are eight translation methods explained by Newmark and the example by Hartono, among them are:

a. Word for Word Translation

" The SL word-order is preserved and the words translated singly by their most common meanings, out of context." It means that word for word translation method keep up about the structure of the text or sentence. Every word translated word by word based on the general meaning or out of the context and the words related to culture translated literally.

Example : SL : Look, little guy, you-all shouldn't be doing that.

TL : Lihat, kecil anak, kamu seтиa harus tidak

melakukan ini.

b. Literal Translation

"The SL grammatical constructions are converted to their nearest TL equivalents but the lexical words are again translated singly, out of context." It means that literal translation is a process of translation that translator search the grammatical construction of source language that is worth it or near with the target language. This method is out of the context. Example: SL: Look, little guy, you-all shouldn't be doing that.

TL: Lihat, anak kecil, kamu semua seharusnya tidak berbuat seperti itu.

c. Faithful Method

"A faithful translation attempts to reproduce the precise contextual meaning of original within the constraints of the TL grammatical structures." It means that in faithful method, translator make an effort reproduces contextual meaning from source text rightly into grammatical structure limits of target text. The words that include culture is translated, but there are still some deviation of language structure and the diction.

Example: SL: Ben is too well aware that he is naughty.

TL: Ben menyadari terlalu baik bahwa ia nakal.

d. Semantic Translation "...only in as far as it must take more account of the aesthetic value." It means that 
semantic translation must consider aesthetic the elements of source text compromises the meaning as long normal.

Example: SL: He is a book-worm.

TL: Dia (laki-laki) adalah seseorang yang suka sekali membaca.

e. Idiomatic Translation

"Idiomatic translation reproduces the 'message' of the original but tends to distort nuances of meaning by preferring colloquialisms and idioms where these do not exist in the original." It means that idiomatic translation translates the message of the original text but tends to distort the original meaning at times by preferring the grammatical and the lexical. The result of this method does not look like result of translation.

Example: SL: I can relate to that.

\section{TL: Aku mengerti maksudnya.}

\section{A. Idiomatic Translation}

Idiomatic translation is one kind of translation. It can be found that the definition of idiomatic translation in Larson's Meaning-Based translation which is writen "Idiomatic translation is meaning-based translations which make every effort to communicate the meaning of the source language text in the natural forms of he receptor language." Based on Larson's statement, idiomatic translation uses meaning-based in the translating process, does not sound like a translation, it sounds like it was written originally in the receptor language.

Newmark expressed "Idiomatic translation reproduces the 'message' of the original but tends to distort nuances of meaning by preferring colloquialisms and idioms where these do not exist in the original". This means that a translator uses an expression or an idiomatic expression in his or her translation to make it more understandable for the readers as the situation becomes more similar to the narative language of the readership..

Usually, some good translations are finished using mixture of a literal transfer of the grammatical units along with some idiomatic translation. So, by doing it, the result of the translation will sound more natural. Here is the example of idiomatic translation according to Margono:

Example with?
TL : Dengan siapa dia

tinggal?

In the example above, we can see that there is a change of structure. The word dengan is place in front of the sentence and it makes the sentence better. The result of translation is easier to understand and accept by the readers.

From the definitions above, it can be concluded that idiom is anunchangeable special phrase whose meaning cannot be traced from the meaning of its constituents.

\section{METHOD}

In this research, the technique of collecting data involves two sources which connect to translation method:

The writer uses two books "The Twilight Saga Breaking Dawn" By Stephenie Meyer and "Awal Yang Baru" Transleted by Monica Dwi Chresnayani. They are books that have some context which is in English Version and Indonesian Version. It has been read by the writer.

For supporting the research the writer analyze and get informations about this research, the writter gets the data and finds the theories by experts from the books and internet to complete this research. It relates to the theory by the experts and approaches that the writter needs to analyze. The writter also gets the informations from the library and dictionary.

In analyzing the data, the writer used descriptive analysis technique to analyze method that used the technique by collecting data and information. The writer used two books (English Version and Indonesian Version) and the title is "The Twilight Saga Breaking Dawn" By Stephenie Meyer and "Awal Yang Baru" Transleted by Monica Dwi Chresnayani.

\section{FINDINGS AND DISCUSSION}

In this chapter, the writer is going to discuss about the analysing the translation in the books. The writer will focus on idiomatic translation method that is used in the translation of "The Twilight Saga Breaking Dawn" By Stephenie Meyer and "Awal Yang Baru" Translated by Monica Dwi Chresnayani.

\section{Findings}

\section{The Description of Data}


In the process of analyzing the data, the writer reads both of the books, so that the writer knows about the content of the books. The writer chooses the part that will be analyzed. After that, the writer compares the languages between source language (English) and target language (Bahasa Indonesia).

Table 4.1 The Description of Data

\begin{tabular}{|c|c|c|c|c|}
\hline NO. & ENGLISH & Pg & BAHASA INDONESIA & $\mathbf{P g}$ \\
\hline 1 & $\begin{array}{l}\text { I couldn't bear to look } \\
\text { around at the reaction. }\end{array}$ & 4 & $\begin{array}{l}\text { Aku tak berani melihat sekeliling } \\
\text { untuk mengetahui reaksi orang- } \\
\text { orang. }\end{array}$ & 16 \\
\hline 2 & Personally, I didn't get it. & 5 & Sejujurnya, aku tidak mengerti. & 17 \\
\hline 3 & $\begin{array}{l}\text { I just couldn't put it } \\
\text { together in my head. }\end{array}$ & 6 & $\begin{array}{l}\text { Rasanya aku tidak mampu } \\
\text { menyatukan ketiga kata itu dalam } \\
\text { benakku. }\end{array}$ & 18 \\
\hline 4 & $\begin{array}{l}\text { Well, at least this made } \\
\text { some sense- if you had a } \\
\text { twisted sence of humor. }\end{array}$ & 7 & $\begin{array}{l}\text { Well, setidaknya ini masuk akal- } \\
\text { kalau selera humormu aneh. }\end{array}$ & 20 \\
\hline 5 & $\begin{array}{l}\text { Course, he isn't supper } \\
\text { thrilled that you're } \\
\text { checking up on him, either. }\end{array}$ & 11 & $\begin{array}{l}\text { Tentu saja, dia juga tidak senang } \\
\text { kau selalu menanyakan kabarnya. }\end{array}$ & 24 \\
\hline 6 & I just can't help wishing. & 11 & Boleh saja kan, berharap. & 24 \\
\hline 7 & $\begin{array}{l}\text { I know the others must give } \\
\text { you a hard time. }\end{array}$ & 11 & $\begin{array}{l}\text { Aku tahu yang lain pasti mengecam } \\
\text { sikapmu. }\end{array}$ & 24 \\
\hline 8 & $\begin{array}{l}\text { And tried not to make a } \\
\text { face when he spied us } \\
\text { sitting together on the } \\
\text { loveseat. }\end{array}$ & 13 & $\begin{array}{l}\text { Dan berusaha tidak mengernyit } \\
\text { waktu melihat kami duduk di sofa } \\
\text { dua dudukan. }\end{array}$ & 26 \\
\hline 9 & $\begin{array}{l}\text { Charlie's glower lightened } \\
\text { a shade. }\end{array}$ & 15 & Kemarahan Charlie sedikit mereda. & 28 \\
\hline 10 & There was a long pause. & 15 & Lama tidak terdengar apa-apa. & 28 \\
\hline 11 & $\begin{array}{l}\text { Charlie, I realize that I've } \\
\text { gone about this out of } \\
\text { order. }\end{array}$ & 15 & $\begin{array}{l}\text { Charlie, aku sadar telah } \\
\text { melakukannya dengan cara tidak } \\
\text { lazim. }\end{array}$ & 28 \\
\hline 12 & $\begin{array}{l}\text { Not that this fact } \\
\text { necessitated marriage in } \\
\text { my book. }\end{array}$ & 16 & $\begin{array}{l}\text { Dalam pandanganku, kenyataan ini } \\
\text { memang tidak mengharuskan } \\
\text { pernikahan. }\end{array}$ & 29 \\
\hline 13 & Knew this was coming. & 17 & Sudah kuduga ini bakal terjadi. & 30 \\
\hline 14 & $\begin{array}{l}\text { I'm a little miffed that you } \\
\text { waited so long to_tell me. }\end{array}$ & 17 & $\begin{array}{l}\text { Aku sedikit kesal karena baru } \\
\text { sekarang kau mengatakannya } \\
\text { padaku. }\end{array}$ & 31 \\
\hline 15 & Back up a second, Mom. & 18 & Tunggu sebentar Mom. & 31 \\
\hline 16 & $\begin{array}{l}\text { Every woman's dream } \\
\text { come true. }\end{array}$ & 27 & Itu impian setiap wanita. & 41 \\
\hline 17 & $\begin{array}{l}\text { More that there was some } \\
\text { way he could have been. }\end{array}$ & 28 & $\begin{array}{l}\text { Bukan sekedar itu saja, dia juga } \\
\text { bisa dengan cara lain. }\end{array}$ & 42 \\
\hline 18 & $\begin{array}{l}\text { I hate taking that away } \\
\text { from you, too. }\end{array}$ & 28 & $\begin{array}{l}\text { Aku tak suka merampas } \\
\text { kemungkinan itu darimu. }\end{array}$ & 42 \\
\hline 19 & $\begin{array}{l}\text { It took me a minute. "I } \\
\text { know what I'm doing" }\end{array}$ & 28 & $\begin{array}{l}\text { Aku terdiam beberapa saat. "Aku } \\
\text { tahu apa yang sedang kulakukan. }\end{array}$ & 42 \\
\hline 20 & $\begin{array}{l}\text { "I'm sorry. I am_moping, } \\
\text { aren't I? Must be nerves." } \\
\text { "Are your feet cold?"" }\end{array}$ & 28 & $\begin{array}{l}\text { "Maafkan aku. Aku memang } \\
\text { bermuram durja, ya? Pasti karena } \\
\text { gugup." }\end{array}$ & 43 \\
\hline
\end{tabular}




\begin{tabular}{|c|c|c|c|c|}
\hline & & & \multicolumn{2}{|l|}{ Kau gugup akan menikah? } \\
\hline 21 & $\begin{array}{l}\text { It was going to be a very } \\
\text { long day tomorrow. }\end{array}$ & 30 & $\begin{array}{l}\text { Besok akan jadi hari yang sangat } \\
\text { melelahkan. }\end{array}$ & 45 \\
\hline 22 & $\begin{array}{l}\text { It would be touchy to have } \\
\text { Tanya's family in the same } \\
\text { room with our guests from } \\
\text { the Quileute reservation, } \\
\text { Jacob's father, and the } \\
\text { Clearwaters. }\end{array}$ & 31 & $\begin{array}{l}\text { Bukan perkara mudah menyatukan } \\
\text { keluarga Tanya dalam satu ruangan } \\
\text { dengan tamu-tamu kami dari } \\
\text { reservasi Quileute, ayah Jacob, dan } \\
\text { keluarga Clearwaer. }\end{array}$ & 46 \\
\hline 23 & $\begin{array}{l}\text { The child opened his bright, } \\
\text { bloodred eyes. }\end{array}$ & 37 & $\begin{array}{l}\text { Bocah itu membuka yang } \\
\text { cemerlang dan semerah darah. }\end{array}$ & 53 \\
\hline
\end{tabular}

\section{DISCUSSION}

In the process of analyzing the data, the writer reads both of the books, so that the writer knows about the content of the books. The writer chooses the part that will be analyzed. After that, the writer compares the languages between source language (English) and target language (Bahasa Indnesia)

1. English (page 4), Indonesian language (page 16)

SL : I couldn't bear to look around at the reaction.

TL : Aku tak berani melihat sekeliling untuk mengetahui reaksi orang-orang.

In the sentence above, the translator translates by using idiomatic translation. The translator translates "bear" to be "berani" and the original meaning of "bear" is "tahan". If it is compared by using wordfor-word translation method, in target language is "Aku tidak tahan melihat reaksi orang-orang sekitar".

2. English (page 5), Indonesian language (page 17)

SL : Personally, I didn't get it.

TL : Sejujurnya, aku tidak mengerti.

From the data above, the translator translates by using idiomatic translation. The translator translates "personally" to be "sejujurnya" and the original meaning of "personally" is "secara pribadi". The translator also translates "get" to be "mengerti" and the original meaning of "get" is "memperoleh". If it is compared word-for-word, it can be "Secara pribadi, saya tidak memperolehnya".

3. English (page 6), Indonesian language (page 18)

SL : I just couldn't put it together in my head.

TL : Rasanya aku tidak mampu menyatukan ketiga kata itu dalam benakku.
In the data above, the writer concludes that the translator uses idiomatic translation method. The translator translates "put" to be "menyatukan" and the original meaning is "put" is "menempatkan". The translator also translates "in my head" should be "dalam benakku" and the original meaning of "in my head" is "di kepalaku". If it is compared by using word-for-word, it can be " $A k u$ tidak mampu menempatkannya secara bersamaan di kepalaku”.

4. English (page 7), Indonesian language (page 20)

SL : Well, at least this made some sense if you had a twisted sence of humor.

TL : Well, setidaknya ini masuk akal kalau selera humormu aneh.

From the data above, the translator translates by using idiomatic translation. The translator translates " a twisted sence of humor" to be "selera humormu aneh". The origin meaning of "a twisted sence" is "perasaan yang memutar. If it is compared by using word-for-word, it becomes "perasaan humor yang memutar".

5. English (page 11), Indonesian language (page 24)

SL : Course, he isn't supper thrilled that you are checking up on him, either.

TL : Tentu saja, dia juga tidak senang kau selalu menanyakan kabarnya.

In the data above, the translator translates by using idiomatic translation method. The translator translates "checking up" to be "menanyakan". The original meaning of "checking up" is "memeriksa". If it is compared by word-for-word, it becomes "Tentu saja, dia tidak senang kau memeriksanya".

6. English (page 11), Indonesian language (page 24)

SL : I just can't help wishing. 
TL : Boleh saja kan, berharap.

From the data above, the translator translates by using idiomatic translation. The translator translates "I just can't" to be "boleh saja kan". The original meaning of "I just can't" is "saya tidak bisa". If it is compared by word-for-word, it can be "Saya tidak bisa berharap".

7. English (page 11), Indonesian language (page 24)

SL : I know the others must give you a hard time.

TL : Aku tahu yang lain pasti mengecam sikapmu.

From the data above, the translator translates by using idiomatic translation method. The translator translates "give" to be "mengecam". The origin meaning of "give" is "memberi". The translator also translates "a hard time" to be "sikapmu". The origin meaning of "a hard time" is "saat yang sulit". If it is compared by word-for-word, it becomes "Aku tahu yang lain pasti memberimu saat yang sulit."

8. English (page 13), Indonesian language (page 26)

SL : And tried to not make a face when he spied us sitting together on the loveseat.

TL : Dan berusaha tidak mengernyit waktu melihat kami duduk di sofa dua dudukan.

From the data above, the translator translates by using idiomatic translation. The translator translates "make a face" to be "mengernyit". The original meaning of "make a face" is "membuat wajah". If it is compared by word-for-word, it can be "Dan berusaha membuat wajah ketika mereka melihat kami duduk Bersama di kursi".

9. English (page 15), Indonesian language (page 28)

SL : Charlie's glower lightened a shade.

TL : Kemarahan Charlie sedikit mereda.

From the data above, the translator translates by using idiomatic translation. The translator translates "lightened" to be "mereda". The original meaning of "lightened" is "meringankan". If it is compared by word-for-word, it can be "Kemarahan Charlie meringankan sebuah bayangan".

10. English (page 15), Indonesian language (page 28)

SL : There was a long pause.

TL : Lama tidak mendengar apa-apa.
From the data above, the translator translates by using idiomatic translation. The translator translates "a long pause" to be "mendengar apa-apa". The original meaning of "a long pause" is "jeda yang panjang". If it is compared by word-forword, it can be "Ada jeda yang panjang".

11. English (page 15), Indonesian language (page 28)

SL : Charlie, I realize that I've gone about this out of order.

TL : Charlie, aku sadar telah melakukannya dengan cara tidak lazim.

From the data above, the translator translates by using idiomatic translation. The translator translates "gone" to be "melakukannya". The original meaning of "gone" is "pergi". The translator also translates "out of order" to be "tidak lazim". The origin meaning of "out of order" is "rusak". If it is compared by word-forword, it can be "Charlie, aku sadar bahwa aku telah pergi tentang ini rusak".

12. English (page 16), Indonesian language (page 29)

SL : Not that this fact necessitated marriage in my book.

TL : Dalam pandanganku, kenyataan ini memang tidak mengharuskan pernikahan.

From the data above, the translator translates by using idiomatic translation. The translator translates "in my book" to be "dalam pandanganku". The original meaning of "in my book" is "di bukuku". If it is compared by word-for-word, it can be "Di bukuku, kenyataan ini memang tidak mengharuskan pernikahan".

13. English (page 17), Indonesian language (page 30)

SL : Knew this was coming.

TL : Sudah kuduga ini bakal terjadi.

From the data above, the translator translates by using idiomatic translation. The translator translates "knew" to be "sudah kuduga". The original meaning of "knew" is "tahu". The translator also translates "coming" to be "bakal terjadi". The original meaning of "coming" is "datang". If it is compared by word-for-word, it can be "Tahu ini sedang datang".

14. English (page 17), Indonesian language (page 31)

SL : I'm a little miffed that you waited so long to tell me. 
TL : Aku sedikit kesal karena baru sekarang kau mengatakannya padaku.

From the data above, the translator translates by using idiomatic translation. The translator translates "that" to be "karena". The original meaning of "that" is "bahwa". The translator also translates "you waited so long" to be "kau baru sekarang". The original meaning of "you waited so long" is "kau menunggu terlalu lama". If it is compared by word-for-word, it can be "Aku sedikit kesal bahwa kamu telah menunggu terlalu lama untuk mengatakannya padaku".

15. English (page 18), Indonesian language (page 31)

SL : Back up a second Mom.

TL : Tunggu sebentar Mom

From the data above, the translator translates by using idiomatic translation. The translator translates "back up" to be "tunggu". The original meaning of "back up" is "kembali". If it is compared by wordfor-word, it can be "Kembali sebentar Mom".

16. English (page 27), Indonesian language (page 41)

SL : Every woman's dream come true.

TL : Itu impian setiap wanita.

From the data above, the translator translates by using idiomatic translation. The translator translates "Every woman's dream come true." to be "Itu impian setiap wanita.". If it is compared by word-forword, it can be "Setiap impian wanita terkabulkan".

17. English (page 28), Indonesian language (page 42)

SL : More that there was some way he could have been.

TL : Bukan sekedar itu saja, dia juga bisa dengan cara lain.

From the data above, the translator translates by using idiomatic translation. The translator translates "more that" to be "bukan sekedar itu saja". The original meaning of "more that" is "lebih dari itu". If it is compared by word-for-word, it can be "Lebih dari itu, ada beberapa cara yang dia bisa".

18. English (page 28), Indonesian language (page 42)

SL : I hate taking that way from you, too.

TL : Aku tak suka merampas kemungkinan itu darimu.
From the data above, the translator translates by using idiomatic translation. The translator translates "hate" to be "tak suka". The original meaning of "hate" is "benci". The translator also translates "that way" to be "kemungkinan". The original meaning of "that way" is "cara itu". If it is compared by word-for-word, it can be "Aku benci merampas cara itu darimu, juga".

19. English (page 28), Indonesian language (page 42)

SL : It took me a minute. "I know what I'm doing"

TL : Aku terdiam beberapa saat. "Aku tahu apa yang aku lakukann"

From the data above, the translator translates by using idiomatic translation. The translator translates "it took me" to be "aku terdiam". The original meaning of "It took me" is "aku butuh". If it is compared by word-for-word, it can be "Aku butuh beberapa saat".

20. English (page 28), Indonesian language (page 43)

SL : "I'm sorry. I am moping, aren't I? Must be nerves". "Are your feet cold?".

TL : "Maafkan aku. Aku memang bermuram durja ya? Pasti karena gugup. "Kau gugup akan menikah?

From the data above, the translator translates by using idiomatic translation. The translator translates "Are your feet cold?" to be "Kau gugp akan menikah". If it is compared by word-for-word, it can be " "Maafkan aku. Aku memang bermuram durja ya? Pasti karena gugup. "Apakah kakimu dingin?".

21. English (page 30), Indonesian language (page 45)

SL : It was going to be a very long day tomorrow.

TL : Besok akan menjadi hari yang melelahkan.

From the data above, the translator translates by using idiomatic translation. The translator translates "a very long day" to be "hari yang sangat melelahkan". The original meaning of "a very long day" is "hari yang sangat panjang". If it is compared by word-for-word, it can be "Besok akan menjadi hari yang sangat panjang".

22. English (page 31), Indonesian language (page 46) 
SL : It would be touchy to have Tanya's family in the same room with our guests from the Quileute reservation, Jacob's father, and the Clearwaters.

TL : Bukan perkara mudah menyatukan keluarga Tanya dalam satu ruangan dengan taти-tamu kami dari reservasi Quileute, ayah Jacob, dan keluarga Cleanwaters.

From the data above, the translator translates by using idiomatic translation. The translator translates "It would be touchy" to be "bukan perkara mudah". The original meaning of "It would be touchy" is "itu akan sensitif". The translator also translates "have" to be "menyatukan". The original meaning of "have" is "memiliki". If it is compared by word-for-word, it can be "Itu akan sensitive untuk memiliki keluarga Tnya dalam satu ruangan dengan tamи-tamu dari reservasi Quileute, ayah Jacob, dan keluarga Cleanwaters".

23. English (page 37), Indonesian language (page 53)

SL : The child opened his bright, bloodred eyes.

TL : Bocah itu membuka mata cemerlang dan semerah darah.

From the data above, the translator translates by using idiomatic translation. The translator translates "bloodred eyes" to be "semerah darah". The original meaning of "bloodred eyes" is "mata berdarah". If it is compared by word-for-word, it can be "Bocah itu membuka matanya yang Cemerlang dan mata berdarah".

\section{CONCLUSION}

After analyzing the data, the writer is going to conclude from this analysis. To analyze the translation, the writer has to do preparation. The first step was preparation, where the writer should have the data that will be analyzed. The data analyzed were books, of which both are in
English version and the second one is Bahasa Indonesia version. The second preparation was reading the books and choosing the data that will be analyzed. After the writer decided the data that will be analyzed, the writer wrote down and started to analyze.

From analyzing the data, the writer found some proofs that the data which were translated used idiomatic translation method. In analyzing translation process, the writer compared with other translation methods. It has purpose that the writer showed the translation method used by the translator was idiomatic translation method.

After knowing the answers to the problem based on the data, the writer expects this paper would considerably benefit for several reasons, among others are:

The writer expects this paper would be useful as a reference for another researcher who are intended to analyze the idiomatic translation from a literature work as the novel genre is an unordinary story which is a fantasy romance genre that is written and arranged as a modern literature work and achieve a great credit and outstanding readers. When writing the papers, the writer intended to show some factual results from examining the idiomatic translation work so the readers could comprehend the exact meaning which contain and is hidden from the sentences in the novel.

Based on this research, the writer would like to recommended students of the English Language Education Study Program to learn about idiomatic expression in daily life. Idiomatic translation exist in formal and informal situations as in the lecture in the classroom activities. As for the lectures of the English Language Education Study Program, the writer would like to recommend that idiomatic translation be included as a material for study in the translation and interpreting class.

\section{REFERENCES}

Anthony, P. (2010). Exploring Translation Theories. New York: Routedge.

Choliludin. (2005). The Technique of Making Idiomatic Translation. Jakarta: Kesaint Black.
Hartono, R. (2009). Teori Penerjemah (A Handbook for Translators). Semarang: CV Cipta Nusantara.

Larson, M.L. (1984). Meaning-Based Translation: A Guide to Cross-Language Equivalent. Lanham Md: University Press of America. 
Muhammad Ajie Akbar and Suhendar

Idiomatic translation method of English Indonesian translation

Mahmoud, O. (2007). Translation Procedures, Strategies, and Method. Translation Journal. Volume 11, No 3, http://translationjurnal.net/journal/41culture. htm. July 2007.

Margono. (1999). Essential of Theory and Practice of Translation. Denpasar: Fakultas Sastra Universitas Udayana.

Munday, J. (2009). The Routledge Companion to Translation Studies Revised Edition. London and New York: Routledge.
Newmark, P. (1988). A Textbook of Translation. China: Pearson Education Limited.

Owji, Z. (2013). Translation Strategies: A Review and Comparison of Theories Journal. Volume 17, No. 1. January 2013.

Selliot, S. and Boer, R. (2012). Ideology, Culture, and Translation. Atlanta. The Society of Biblical Literature.

Zakhir, M. and Gross, S. (2009). The Theories of Translation From History to Procedures. Morocco. 